Travaux du Muséum National d'Histoire Naturelle «Grigore Antipa»

Vol. LV (1)

pp. 57-63

(C) 31 août 2012

DOI: $10.2478 / \mathrm{v} 10191-012-0006-\mathrm{x}$

\title{
SONG DESCRIPTION OF ZUBOVSKI'S BUSH-CRICKET, ISOPHYA ZUBOWSKII (ORTHOPTERA: PHANEROPTERIDAE)
}

\author{
IONUȚ ȘTEFAN IORGU, ELENA IULIA IORGU
}

\begin{abstract}
The bush-cricket Isophya zubowskii Bey-Bienko, 1954 was surveyed in the period 20022012 in 11 locations from Romania. The calling song, described hereby for the first time, consists of a long series of syllables, each formed by $85-118$ impulses and lasting for $236-319 \mathrm{~ms}$ in the populations near Iaşi, while the individuals from three other populations in Southern Romania produce shorter syllables, consisting of 74-105 impulses and, lasting for 182-251 ms. Sound frequency ranges in the interval $10-40 \mathrm{kHz}$, with highest peak at about $18-26 \mathrm{kHz}$. Based on the description of its calling song, we conclude that Isophya zubowskii belongs to the Isophya kraussii species group.
\end{abstract}

Résumé. La sauterelle Isophya zubowskii Bey-Bienko, 1954 a été surveillée pendant 2002-2012 dans 11 différents localités de Roumanie. La stridulation d'Isophya zubowskii, décrite ici pour la première fois, se compose d'une longue série de syllabes, chacune formée par 85-118 impulsions et d'une durée de 236-319 ms dans les populations situées près d'Iaşi, tandis que les individus de trois autres populations du sud de la Roumanie produisent des syllabes plus courtes, composé de 74-105 impulsions, d'une durée de $182-251 \mathrm{~ms}$. La fréquence d'émission sonore est située dans l'intervalle $10-40 \mathrm{kHz}$, avec la fréquence du maximum d'énergie entre $18-26 \mathrm{kHz}$. Sur la base de la description de son chant d'appel, nous concluons qu'Isophya zubowskii appartient au groupe d'espèces Isophya kraussii.

Key words: Isophya, bioacoustics, Romania, distribution.

\section{INTRODUCTION}

Genus Isophya is one of the biggest of Palaearctic Orthoptera, with 89 species known so far and 45 species present in Europe (Eades et al., 2012). Most of the Isophya species occur in Southern and Eastern Europe, the Caucasus and Asia Minor, the last one being considered the radiation center of the genus (La Greca, 1999). Many of them have small distribution ranges with specific topographic and habitat affinities (Bauer \& Kenyeres, 2006; Sevgili et al., 2006).

Within the genus, several groups of sibling species were identified (Heller, 1988; Sevgili et al., 2006; Warchałowska-Śliwa et al., 2008; Chobanov, 2009). The genus represents a taxonomic challenge for specialists because species identification within these groups is hampered by the similarity in morphological traits and lack of sclerotized genitalia (Heller et al., 2004; Warchałowska-Sliwa et al., 2008). The most utilized tool for discriminating Isophya sympatric taxa and disentangling taxonomic relations is the study of males' song patterns (Heller, 1988; Sevgili, 2003; Heller et al., 2004; Orci et al., 2010). The examination of acoustic signals can also provide information on phylogenetic relationship between species (Chobanov, 2009) and helps in the detection of elusive individuals in the field (Orci et al., 2010).

Isophya zubowskii occurs in Eastern and Southern Romania, Republic of Moldova and Ukraine (Heller, 2012). The bush-cricket inhabits sunny mesophilic grasslands, forest ecotone and clearings, usually preferring broad-leafed dicotyledonous plants. The most appropriate habitat conditions for this bush-cricket are steppic and forest steppic areas located in Prut River Basin, Eastern Siret River 
Basin, Northern Dobrogea and Romanian Plain. First larvae are to be found in April, while imagoes develop in late May and June (Iorgu \& Iorgu, 2008).

Although there are many papers that describe the acoustic signals of various Isophya species, several taxa remain with the song features unknown, including Isophya zubowskii Bey-Bienko, 1954. The aim of the present study is to describe the calling song pattern of $I$. zubowskii from several populations occurring in Romania.

\section{MATERIAL AND METHODS}

The specimens were caught alive in the wild and transported in plastic recipients. The individuals have been identified using the keys of Kis (1976) and Harz (1969). The Scanning Electron Microscope (SEM) pictures were made with a Tescan Vega SEM at "Al. I. Cuza" University of Iaşi, after coating the specimens with gold in an EMS 550X sputter coater. For the bioacoustic study, males and females have been recorded indoors, using the digital recorders Sony ICD SX56 and EDIROL R-09HR. Wing movements during the song have been video recorded with a Canon EOS digital camera, equipped with a $100 \mathrm{~mm} \mathrm{1:1} \mathrm{macro} \mathrm{lens.} \mathrm{Song} \mathrm{terminology}$ follows Ragge \& Reynolds (1998) and Heller et al. (2004). The oscillographic and spectrographic analyses of sound were made with Audacity 1.3.

\section{RESULTS AND DISCUSSIONS}

Order Orthoptera

Suborder Ensifera

Family Phaneropteridae

\section{Isophya zubowskii Bey-Bienko, 1954}

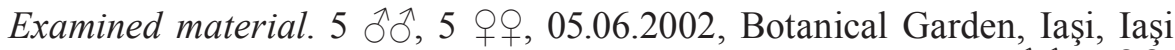
county, $47^{\circ} 11^{\prime} 11.45^{\prime \prime} \mathrm{N}, 27^{\circ} 33^{\prime} 06.56$ 'E, $101 \mathrm{~m}$ a.s.l. (leg. I. Şt. Iorgu); 6 ò $^{\lambda}, 4$ 우,

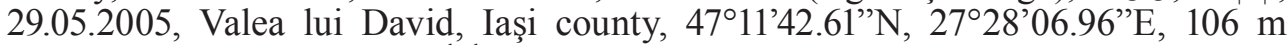
a.s.l. (leg. I. Şt. Iorgu); 15 $\widehat{\partial}, 11$ oq, 31.05.2005, Bârnova forest, near Curături,

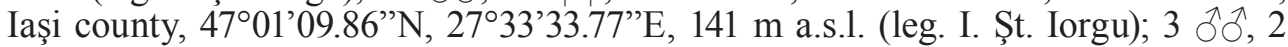

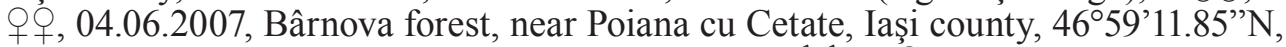

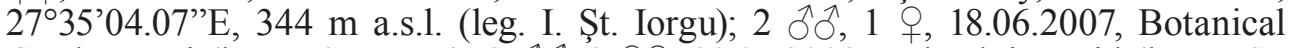
Garden, Iaşi (leg. I. Şt. Iorgu); 2 đ̂̉, 3 + ,, 30.05 .2008 , Valea lui David (leg. I. Şt.
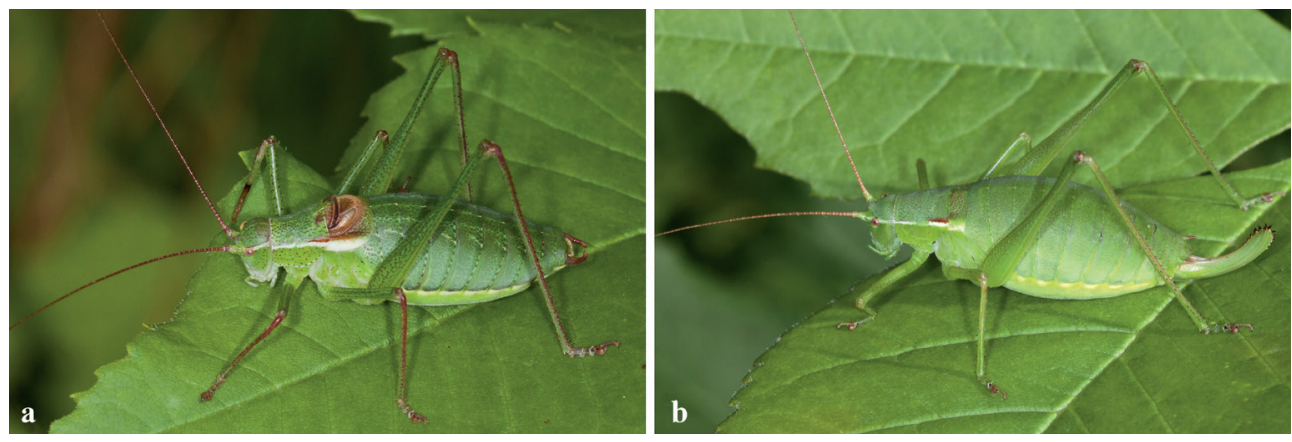

Fig. 1 - a, Isophya zubowskii, habitus 今̄; b, Isophya zubowskii, habitus $\bigcirc$ (Comana, 25.06.2010; photos: I. Şt. Iorgu). 


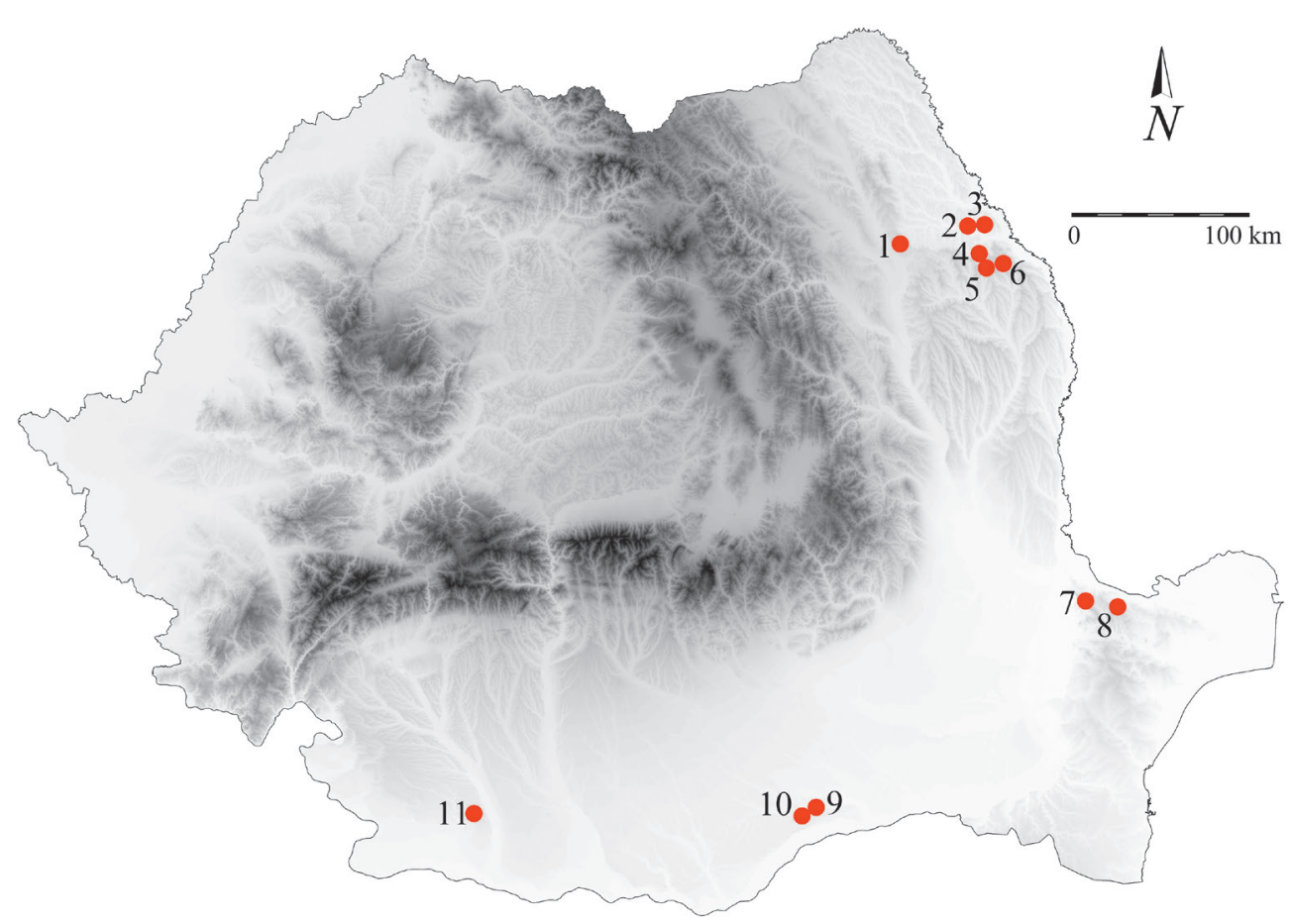

Fig. 2 - Occurrence records of Isophya zubowskii in Romania: 1, Miclăuşeni; 2, Valea lui David; 3, Botanical Garden Iaşi; 4, Curături; 5, Poiana cu Cetate; 6, Dobrovăţ; 7, Greci; 8, Niculiţel; 9, Comana; 10, Vlad Ţepeş; 11, Cobia.

Iorgu \& E. I. Iorgu); 1 ○, 1 ๆ, 17.06.2008, Botanical Garden, Iaşi (leg. I. Şt. Iorgu); 8 ơ A, 9 o 9 , 30.05.2009, Bârnova forest, near Poiana cu Cetate (leg. I. Şt. Iorgu); 1

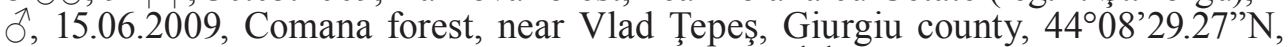

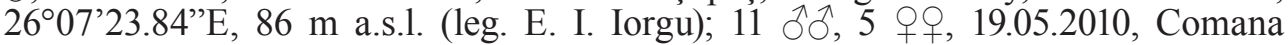

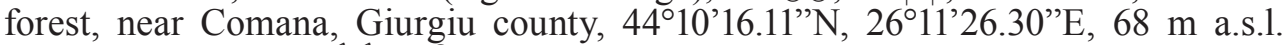
(leg. I. Şt. Iorgu); $3 \hat{\jmath} \hat{\jmath}, 1$ O , 27.05.2010, Cobia forest, near Calopăr, Dolj county,

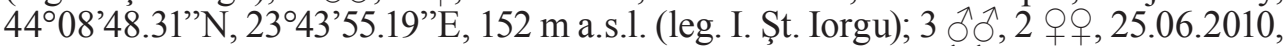
Comana forest, near Comana (leg. I. St. Iorgu) (Fig. 1); 6 J $\delta, 3$ oxo, 09.05.2011,

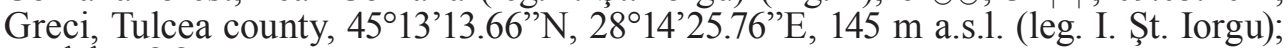

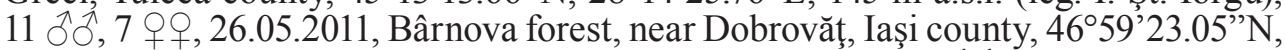

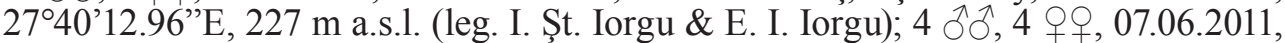
Niculiţel, Tulcea county, $45^{\circ} 09^{\prime} 45.66^{\prime \prime} \mathrm{N}, 28^{\circ} 28^{\prime} 52.54^{\prime} \mathrm{\prime}$, $330 \mathrm{~m}$ a.s.l. (leg. I. Şt.

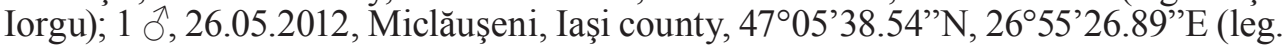
I. Şt. Iorgu) (Fig. 2).

This is the first record of the species West of Olt River, Cobia forest representing the new South-Western border of its distribution area.

Audio recorded material. 1 đ, 04.06.2007, Bârnova forest, near Poiana cu Cetate (air temperature $20^{\circ} \mathrm{C}$ ); $2 \mathrm{o}^{\lambda}, 19.05 .2010$, Comana forest, near Comana (air temperature $18^{\circ} \mathrm{C}$ ); $2 \hat{\delta} \hat{\partial}, 27.05 .2010$, Cobia forest, near Calopăr; (air temperature

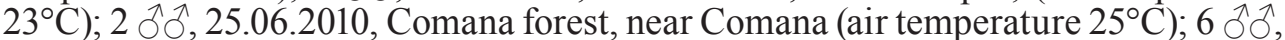
26.05.2011, Bârnova forest, near Dobrovăţ (air temperature $21^{\circ} \mathrm{C}$ ); $3{ }^{\lambda} \delta^{\lambda}, 07.06 .2011$, Niculiţel (air temperature $24^{\circ} \mathrm{C}$ ). 


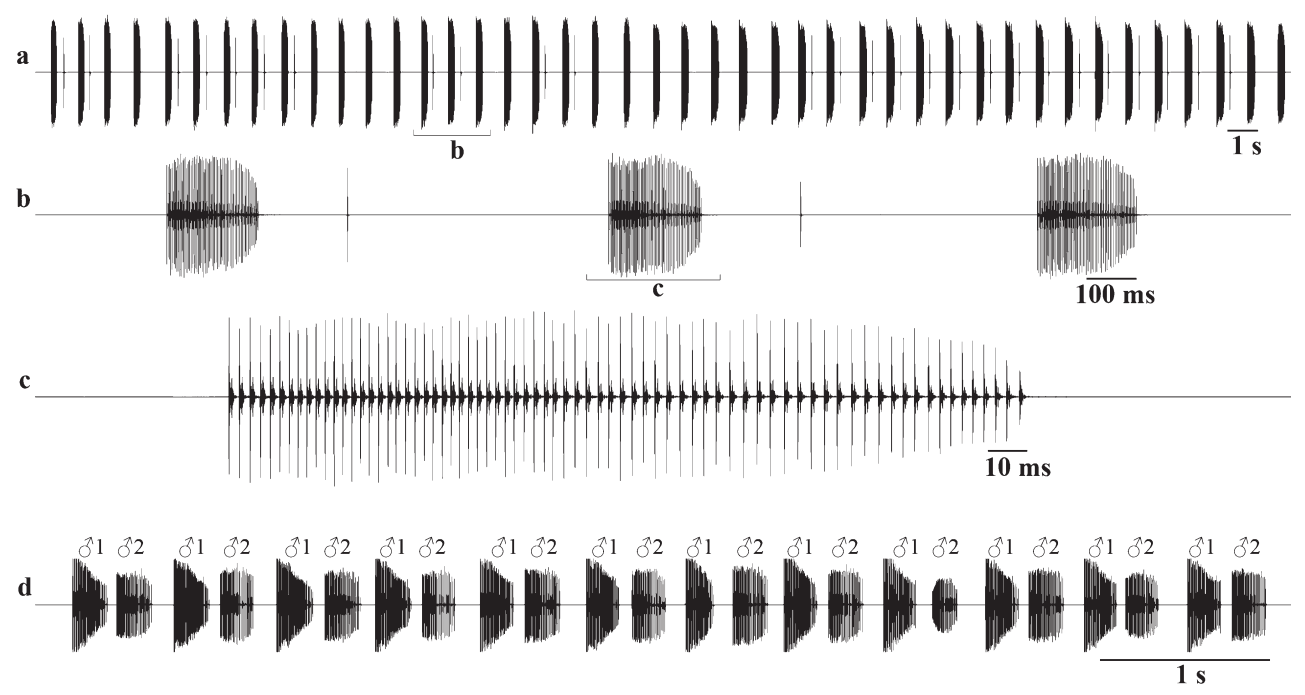

Fig. 3 - Oscillographic analysis of sound in Isophya zubowskii: a, calling song; b, c, detailed syllables; $\mathrm{d}$, rivalry song of two males (temperature $21^{\circ} \mathrm{C}$ ).

Bioacoustics. As most of the other Isophya species, this bush-cricket also sings only at dusk and during the night. Male's calling song consists of a temporal variable series of syllables, lasting from a few seconds to more than 4 minutes, repeated at a rate of about 62-81 / minute (Fig. 3). All sounds are produced when the insect closes the tegminae. The syllables are composed of 74-118 impulses (mean \pm SD: $94.2 \pm$ 10.1.) and last for 182-319 ms (mean \pm SD: $225.7 \pm 33.4$ ) (Tab. 1). Towards the end of each syllable, impulses gradually descend in amplitude; the break between two successive syllables is about 432-1127 ms. Often, an after-click follows the syllable after a period of 110-180 ms.

The longest syllables were recorded in individuals from the surroundings of Iaşi (236-319 ms), while the individuals from the southern part of species distribution area produce shorter syllables $(182-251 \mathrm{~ms})$. The number of pegs on the stridulatory file also differs in the analyzed populations: 227 pegs were observed in a male from Dobrovăţ, 181 in a male from Comana, 212 at Cobia and 203 pegs in a male collected at Niculiţel (Fig. 4). These differences in stridulatory files explain the dissimilarities

Table 1

Song characteristics of Isophya zubowskii in Romania ( $\mathrm{n}=$ number of recorded males).

\begin{tabular}{clccccc} 
Male song & Location & $\mathrm{n}$ & Maximum & Minimum & Mean & SD \\
\hline \multirow{3}{*}{ number of impulses in a syllable $\left({ }^{3}\right)$} & Dobrovăț & 4 & 118 & 85 & 101.5 & 10.3 \\
& Comana & 4 & 88 & 74 & 80.9 & 5.7 \\
& Cobia & 2 & 105 & 97 & 99.7 & 2.2 \\
& Niculițel & 3 & 100 & 92 & 94.9 & 3.2 \\
\hline \multirow{3}{*}{ syllable duration $\left({ }^{(}\right)(\mathrm{ms})$} & Dobrovăț & 4 & 319 & 236 & 269.8 & 28.6 \\
& Comana & 4 & 251 & 182 & 216.1 & 27.5 \\
& Cobia & 2 & 234 & 191 & 207.3 & 13 \\
& Niculițel & 3 & 231 & 188 & 209.9 & 13.5 \\
\hline
\end{tabular}



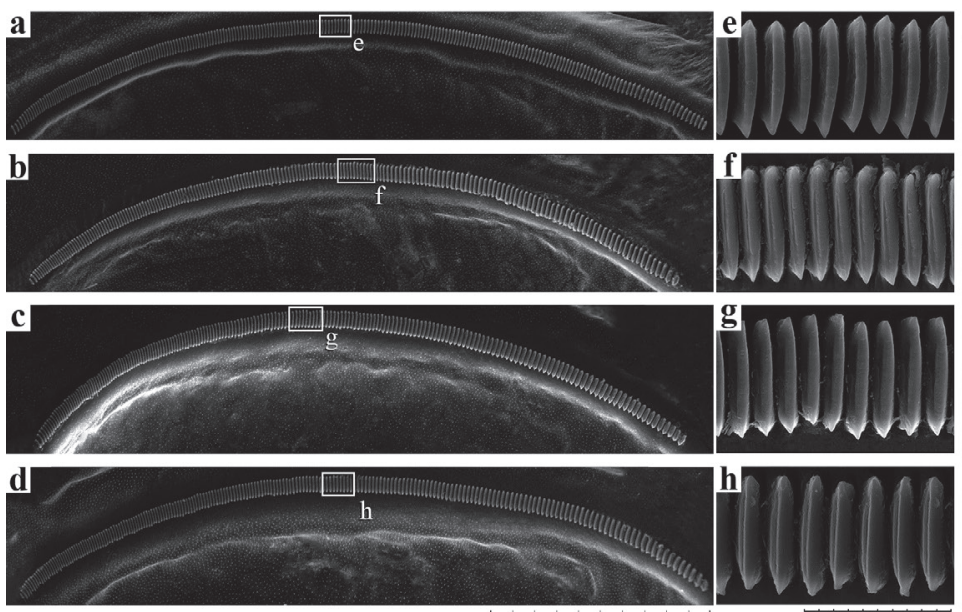

$1 \mathrm{~mm}$

$100 \mu \mathrm{m}$

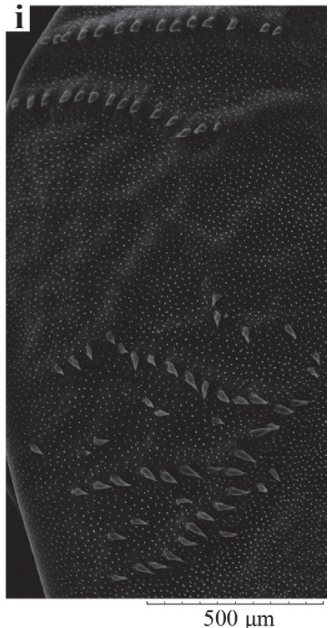

Fig. 4 - Stridulatory file in Isophya zubowskii from: a, e, Dobrovăț; b, f, Comana; c, g, Cobia; d, h, i, Niculițel (a-h, males; i, female; e, f, g, h, detailed areas of male stridulatory file) (SEM photos).

in syllable length and impulse number in individuals from distinct populations. Females also have stridulatory bristles on the wings (Fig. 4 i), but in our experiments they did not sing as male acceptance for mating and only approached silently when willing to mate with the singing male.

Male rivalry song was noticed occasionally. Males try not to stay close to each other for too long and usually one of them leaves the area. In such situation, males produce the regular song, sometimes overlapping the syllables in the duet. Syllable length, number of impulses and period between successive syllables are not affected (Fig. 3 d).

The song frequency in the four studied populations varies without significance, the main impulse series' frequency ranging between 10-40 kHz. However, the highest peak is variable: about $21 \mathrm{kHz}$ at Dobrovăţ, $26 \mathrm{kHz}$ at Comana, $18 \mathrm{kHz}$ at Cobia and about $22 \mathrm{kHz}$ at Niculiţel (Fig. 5).

In 2008, Warchałowska-Śliwa et al. stated that Isophya zubowskii might belong to the one of the closely related species groups I. costata or I. kraussii. The I. costata group contains moderately large to large species with long pronotal discwidened in metazona, distinctly widened and short tegminae, cerci variable in shape and moderately short to long ovipositor (Warchałowska-Śliwa et al., 2008). In I. costata, the stridulatory file bears 250-280 pegs and the song consists of isolated syllables, each composed of 102-130 impulses followed by a series of 1-17 afterclicks (Heller et al., 2004). Males of I. stysi have 54-133 pegs on the stridulatory file and produce syllables of 20-60 impulses, lasting for $110-270 \mathrm{~ms}$, while in $I$. modestior, the stridulatory file has 117-167 pegs and the syllables last for 127-260 ms, being formed by a number of 35-80 impulses (Orci et al., 2005; I. SSt. Iorgu, unpublished). Syllables in I. stysi begin with a few temporally distinct impulses. Isolated after-clicks were recorded in both $I$. stysi and I. modestior.

Isophya kraussii group contains moderate sized species with long pronotal disc, widened in metazona, distinctly shortened tegminae, moderately stout to moderately slender cerci, with gradually curved apex and moderately short ovipositor (Warchałowska-Sliwa et al., 2008). In this group, the syllables of I. pienensis are 

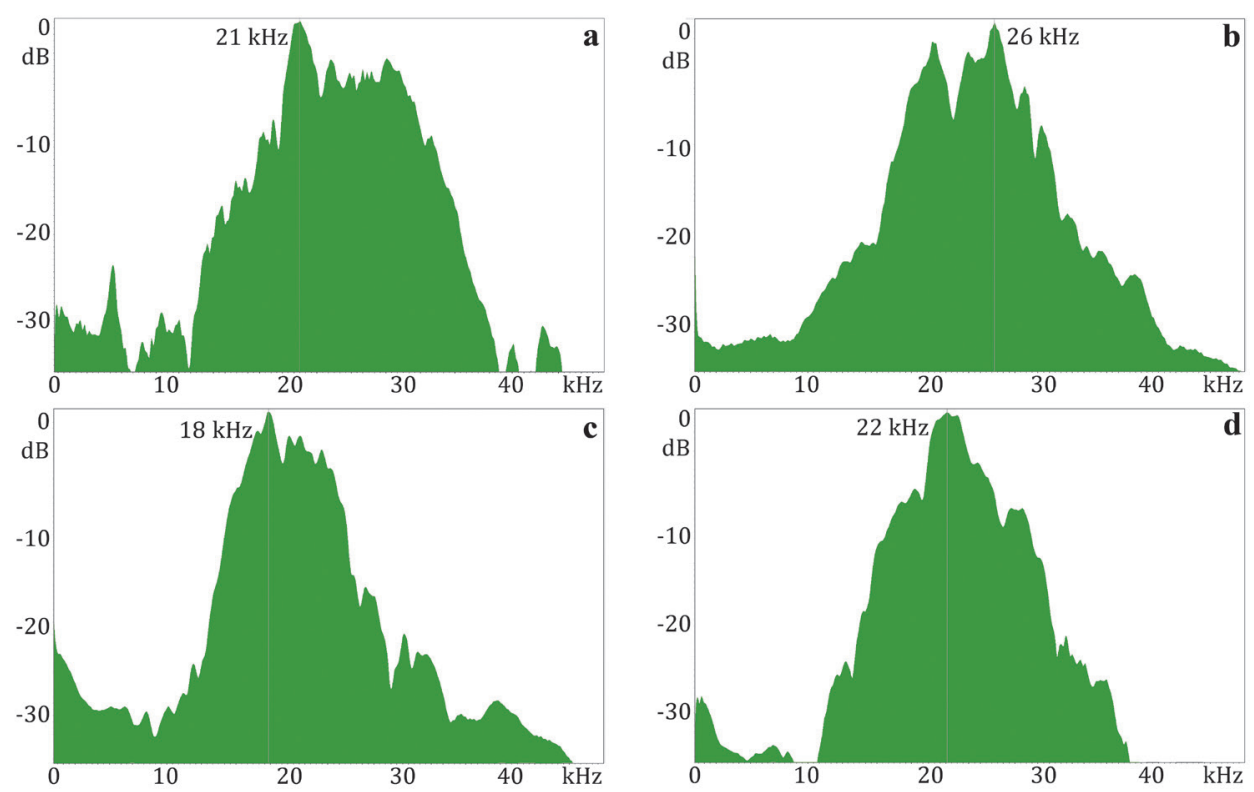

Fig. 5 - Spectral analysis of sound in Isophya zubowskii males from: a, Dobrovăţ; b, Comana; c, Cobia; d, Niculiţel.

long, consisting of 76-105 impulses and lasting for 300-510 ms, while I. kraussii produces shorter syllables: 80-125 impulses, lasting for 250-364 ms (Heller et al., 2004). The stridulatory file has a very high number of teeth in the species from this group: 180-225 in Isophya pienensis and 260-305 in I. kraussii (Heller et al., 2004; Iorgu, 2011).

Based on the structure of the calling song and on morphological traits, especially the structure of cerci and tegminae, Isophy a zubowskii is better placed in I. kraussii group.

\section{ACKNOWLEDGEMENTS}

Ionuţ Ştefan Iorgu's work was supported by a post-doctoral fellowship accorded through the programme POSDRU/89/1.5/S/63663 "Developing the innovation capacity and improving the impact of research through post-doctoral programmes". The authors acknowledge Mr. Dumitru Răileanu for taking the SEM photos and the anonymous reviewers, whose advice improved the paper.

\section{DESCRIEREA STRIDULAŢIEI LA COSAŞUL LUI ZUBOVSKI, ISOPHYA ZUBOWSKII (ORTHOPTERA: PHANEROPTERIDAE)}

\section{REZUMAT}

Cosaşul Isophya zubowskii Bey-Bienko, 1954 a fost cercetat în perioada 2002-2012 din 11 situri situate în România. Stridulaţia cosaşului I. zubowskii, descrisă pentru prima dată în această lucrare, constă într-o serie lungă de silabe, formate din 85-118 impulsuri şi care durează 236-319 ms în populațiile din împrejurimile oraşului Iaşi, în timp ce indivizii din alte 3 populații din sudul României au silabe relativ mai scurte, compuse din 74-105 impulsuri şi durând 182-251 ms. Frecvenţa sunetului se încadrează între 10-40 kHz, cu maximul între 18-26 kHz. În urma descrierii stridulaţiei la această specie, putem afirma că I. zubowskii aparţine grupului Isophya kraussii. 


\section{LITERATURE CITED}

BAUER, N., Z. KENYERES, 2006 - Habitat preference studies of some species of the genus Isophya Brunner von Wattenwyl, 1878 (Orthoptera: Phaneropteridae) in the Western part of the Carpathian Basin. Journal of Orthoptera Research, 15 (2): 175-185.

CHOBANOV, D. P., 2009 - Phylogeny and systematics of the Isophya modesta group (Phaneropteridae) based on morphology and bioacoustics. Metaleptea, 29: 20-27.

EADES, D. C., D. OTTE, M. M. CIGLIANO, H. BRAUN, 2012 - Orthoptera Species File Online. Version 2.0/4.0. http://Orthoptera.SpeciesFile.org (accessed at 11 February 2012).

HARZ, K., 1969 - Die Orthopteren Europas I. Series Entomologica, 5: 1-749.

HELLER, K.-G., 1988 - Bioakustik der europäischen Laubheuschrecken. Margraf. Weikersheim. 358 pp.

HELLER, K.-G., 2012 - Fauna Europaea: Arthropoda, Insecta, Orthoptera. Fauna Europaea version 2.4. http://www.faunaeur.org (accessed at 14 February 2012).

HELLER, K.-G., K. M. ORCI, G. GREIN, S. INGRISCH, 2004 - The Isophya species of Central and Western Europe (Orthoptera: Tettigonioidea: Phaneropteridae). Tijdschrift voor Entomologie, 147: 237-258.

IORGU, I. S.., 2011 - Bioacoustics of two newly recorded bush-crickets in the historical region of Moldavia: Isophya pienensis and Isophya sicula (Insecta: Orthoptera). Actual problems of protection and sustainable use of the animal world diversity, Chişinău: 117-119.

IORGU, I. Ş., E. I. IORGU, 2008 - Bush-crickets, crickets and grasshoppers from Moldavia (Romania). Pim Iași. 294 pp.

KIS, B., 1976 - Cheie pentru determinarea ortopterelor din România. Partea I Subord. Ensifera. Muzeul Brukenthal Științele Naturii - Studii și Comunicări, 20: 123-166. (in Romanian)

LA GRECA, M., 1999 - Il contributo degli Ortotteri (Insecta) alla conoscenza della biogeografia dell'Anatolia: la componente gondwaniana. Biogeographia, 20: 179-200.

ORCI, K. M., G. SZÖVÉNYI, B. NAGY, 2010 - A characterization of the pair forming acoustic signals of Isophya harzi (Orthoptera, Tettigonioidea, Phaneropteridae). Acta Zoologica Academiae Scientiarum Hungaricae, 56 (1): 43-53.

ORCI, K. M., B. NAGY, G. SZÖVENYI, I. A. RACZ, Z. VARGA, 2005 - A comparative study on the song and morphology of Isophya stysi and I. modestior (Orthoptera, Tettigoniidae). Zoologischer Anzeiger - A Journal of Comparative Zoology, 244: 31-42.

RAGGE, D. R., J. W. REYNOLDS, 1998 - The songs of the Grasshoppers and Crickets of Western Europe. Harley Books. Cholchester, Essex, England. 591 pp.

SEVGILI, H., 2003 - A new species of bushcricket (Orthoptera: Tettigoniidae) of the Palearctic genus Isophya (Phaneropterinae) from Turkey. Entomological News, 114: 129-137.

SEVGILI, H., B. ÇIPLAK, K.-G. HELLER, A. DEMIRSOY, 2006 - Morphology, bioacoustics and phylogeography of the Isophya major group (Orthoptera: Tettigoniidae: Phaneropterinae): a species complex occurring in Anatolia and Cyprus. European Journal of Entomology, 103 (3): 657-671.

WARCHAŁOWSKA-ŚLIWA, E., D. P. CHOBANOV, B. GRZYWACZ, A. MARYAŃSKANADACHOWSKA, 2008 - Taxonomy of the genus Isophya (Orthoptera, Phaneropteridae, Barbitistinae): comparison of karyological and morphological data. Folia biologica (Kraków), 56: $227-241$.

Received: May 28, 2012

Accepted: August 2, 2012
Ionuţ Ştefan Iorgu

"Alexandru Ioan Cuza" University, Faculty of Biology

Bvd. Carol I, no. 22, 700505, Iaşi, Romania

"Grigore Antipa" National Museum of Natural History

Şos. Kiseleff 1, 011341 Bucharest 2, Romania

e-mail: nusi81@yahoo.com

Elena Iulia Iorgu

"Grigore Antipa" National Museum of Natural History

Şos. Kiseleff 1, 011341 Bucharest 2, Romania

e-mail: elenap@antipa.ro 